\title{
AFFIRMATIVE ACTION AND THE “INDIVIDUAL” RIGHT TO EQUAL PROTECTION
}

\author{
Robert C. Farrell ${ }^{*}$
}

When the Supreme Court, or one its Justices, writes an opinion invalidating a race-conscious affirmative action program, it is commonplace for the opinion to note that the rights protected by the Equal Protection Clause are "individual" or "personal," and thus require the state to treat every person as an individual, not simply as a member of a class. ${ }^{1}$ This assertion about the nature of equal protection rights is assumed to be inconsistent with the classbased underpinning of affirmative action programs, and thus determinative of their invalidation. The problem with affirmative action programs, under this view, is that they ignore the individual characteristics of the persons affected and instead assign different treatment to persons based on their membership in a class. If, for example, the University of California Medical School at Davis assigns a certain number of seats in its entering class to black, Chicano, Asian, and Native-American applicants, ${ }^{2}$ it has made overly broad assumptions about the characteristics of the members of those classes, and then assigned a benefit on the basis of class membership without regard to individual merit or accomplishment.

In a constitutional system where the protection of individual rights is a paramount concern, this argument appears to be powerfully persuasive. Under a different clause of the Constitution, such as the Due Process Clause, an individual rights argument might be undeniably correct. This article, however, will demonstrate that, under the Equal Protection Clause, the individual rights claim is ultimately unavailing. Without regard to the ultimate constitutional validity or invalidity of any affirmative action program, this much is clear: individual rights reasoning is, under longstanding and consistent Supreme Court precedent, irrelevant to the constitutional legitimacy of affirmative action programs. Notwithstanding occasional claims to the contrary, the Equal Protection Clause does not prevent the government from treating individuals as members of a class. In fact, the process of classification is an essential

\footnotetext{
* $\quad$ B.A., Trinity College; M.A., City University of New York; J.D., Harvard University; Professor of Law, Quinnipiac University School of Law. The author thanks William Dunlap for his help.

1. See infra Section III.A.

2. See Regents of the Univ. of Cal. v. Bakke, 438 U.S. 265, 274 (1978).
} 
element of government by law. Every law classifies ${ }^{3}$ and thus treats individual persons as members of a class, without regard to their individual characteristics.

Challenges to affirmative action programs are simply a particular kind of challenge to a particular kind of classification. Individual rights reasoning should play no role in an equal protection challenge to the overall validity of a classification. In the ordinary case, rather, all that matters is that the classification satisfies the requirement of reasonableness, ${ }^{4}$ without regard to the harm that may result to an individual from the proper application of a reasonable classification. Since racial classifications are subject to the heightened standard of judicial review known as strict scrutiny, ${ }^{5}$ affirmative action programs that use race as a factor will frequently violate the Equal Protection Clause. The reason for invalidation in this context is that the race classification does not satisfy the strict scrutiny standard, not because the classification inadequately protects individual rights. Gender classifications are subject to a heightened standard (but lesser than strict scrutiny). ${ }^{6}$ Not surprisingly, given the less-demanding standard, these affirmative action programs are routinely upheld, notwithstanding their negative impact on the individual rights of some of those affected. ${ }^{7}$ When a state decides to create an affirmative action program based on a classification that is neither suspect nor quasi-suspect, such a program would almost certainly be upheld, based on the minimal level of scrutiny it would receive and notwithstanding its negative impact on those adversely affected. ${ }^{8}$

3. See Romer v. Evans, 517 U.S. 620, 631 (1996) (“[Most] legislation classifies for one purpose or another, with resulting disadvantage to various groups or persons."); Toll v. Moreno, 458 U.S. 1, 39 (1982) (Rehnquist, J., dissenting) ("All laws classify, and, unremarkably, the characteristics that distinguish the classes so created have been judged relevant by the legislators responsible for the enactment."); Pers. Adm'r of Mass. v. Feeney, 442 U.S. 256, 271-72 (1979) ("Most laws classify, and many affect certain groups unevenly, even though the law itself treats them no differently from all other members of the class described by the law."); Michael J. Perry, Modern Equal Protection: A Conceptualization and Appraisal, 79 Colum. L. REv. 1023, 1068 (1979) ("Every time an agency of government formulates a rule in particular every time it enacts a law-it classifies.").

4. E.g., Nordlinger v. Hahn, 505 U.S. 1, 11 (1992) ("The appropriate standard of review is whether the difference in treatment . . . rationally furthers a legitimate state interest.").

5. E.g., Grutter v. Bollinger, 539 U.S. 306, 326 (2003) ("This means that such [racial] classifications are constitutional only if they are narrowly tailored to further compelling governmental interests.").

6. E.g., Craig v. Boren, 429 U.S. 190, 197 (1976) (“[C]lassifications by gender must serve important governmental objectives and must be substantially related to achievement of those objectives.").

7. See infra text accompanying notes 183-86 (concerning the relationship between gender classifications and individual burdens).

8. E.g., Pers. Adm'r of Mass. v. Feeney, 442 U.S. 256 (1979) (upholding preference for veterans 
This article examines and rejects the misleading claim that the individual or personal nature of equal protection is inconsistent with affirmative action programs that use race or gender as a classifying tool. Part I reviews the basic idea of equality as a comparative right and the relationship between equality and classifications. Part II surveys the longstanding history in the Supreme Court of treating equal protection as a limit on government classifications and nothing more. Part III critically examines the Supreme Court's occasional pronouncements on equal protection as a personal right, with particular emphasis on the affirmative action context.

\section{THE CONCEPTION OF EQUALITY AS A LIMIT ON GOVERNMENTAL CLASSIFICATION}

The command of equality is essentially comparative. ${ }^{9}$ It requires a comparison of one entity with another entity. Since Aristotle, we have understood the rule of equality to involve the comparative command that those similarly situated should be treated similarly. ${ }^{10}$ Although it is possible to make equality arguments that compare one person to another, the more common kind of equality argument, particularly in the legal sphere, is the one that compares two classes of persons. In this sense, to classify is to identify a trait that makes a person a member of a class (all those over fifty, for example) and then to ascribe a certain treatment (such as forced retirement) for those who, having the trait, are members of the class. ${ }^{11}$ The typical equality challenge to this kind of classification compares one class of persons (those over fifty, who have the trait) with a second class (those under fifty, who do not) and then argues that, since the two classes are similarly situated, the members of both classes should be treated similarly.

The Supreme Court has developed standards of review to determine the degree of scrutiny that a court will apply when deciding whether a classification satisfies the demands of the Equal Protection Clause. The most

in state hiring).

9. See, e.g., Griffin Indus. Inc. v. Irvin, 496 F.3d. 1189, 1205 (11th Cir. 2007) (“Adjudging equality necessarily requires comparison.”); Buckles v. Columbus Mun. Airport Auth., No. CS-00-986, 2002 WL 193853 at *13 (S.D. Ohio Jan. 14, 2002) (“An equal protection claim simply cannot exist absent an allegation that, compared to others, the plaintiff was treated less favorably.").

10. Peter Westen, The Empty Idea of Equality, 95 HARV. L. REV. 537, 543 (1982) (quoting ARistotle, ETHiCA NicomacheA V.3.1131a-1131b (W. Ross trans., 1925)).

11. The classic treatment of the process of classification and its place in the making of equal protection arguments is definitively discussed in Joseph Tussman \& Jacobus tenBroek, The Equal Protection of the Laws, 37 CAL. L. REv. 341 (1949). 
basic is the rational basis standard, which requires that a classification be rationally related to a permissible governmental interest. ${ }^{12}$ Where suspect classifications or fundamental rights are involved, the Court insists on one of two higher standards of review (intermediate ${ }^{13}$ and strict scrutiny ${ }^{14}$ ) that require a closer fit between classification and purpose.

Since equal protection arguments usually challenge the validity of a classification, it is very rare that individual rights reasoning is relevant to the outcome of an equal protection case. There are three, relatively rare, exceptions in which individual rights reasoning is relevant: (1) the selective enforcement equal protection claim, where the government enforces a law selectively against an individual with bad faith motivation, ${ }^{15}(2)$ the class-ofone equal protection claim, where an individual claims that the government has treated him or her differently treated from similarly situated people without a rational basis, ${ }^{16}$ and (3) the claim that involves the bad faith misapplication of a rule to a particular person. ${ }^{17}$ In these three very limited contexts, it might make sense to speak of equal protection as an individual right. These exceptional situations, however, are unconnected to affirmative action claims, which involve challenges to the overall validity of a classification. This paper will demonstrate that, when a challenge is made to

12. E.g., Nordlinger v. Hahn, 505 U.S. 1, 11 (1992) ("The appropriate standard of review is whether the difference in treatment . . r rationally furthers a legitimate state interest.").

13. E.g., Craig v. Boren, 429 U.S. 190, 197 (1976) ("[C]lassifications by gender must serve important governmental objectives and must be substantially related to achievement of those objectives.").

14. Grutter v. Bollinger, 539 U.S. 306, 326 (2003) ("This means that such [racial] classifications are constitutional only if they are narrowly tailored to further compelling governmental interests."); Roe v. Wade, 410 U.S. 113, 155 (1973) ("Where certain fundamental rights are involved, the Court has held that regulation limiting these rights may be justified only by a 'compelling state interest,' and that legislative enactments must be narrowly drawn to express only the legitimate state interests at stake." (citations omitted)).

15. E.g., Harlen Assoc. v. Village of Mineola, 273 F.3d. 494, 499 (2d Cir. 2001) (finding a selective enforcement equal protection claim where a plaintiff can prove that there was different treatment from similarly situated individuals and that such differential treatment was based on "impermissible considerations such as race, religion, intent to inhibit or punish the exercise of constitutional rights, or malicious or bad faith intent to injure a person.").

16. Village of Willowbrook v. Olech, 528 U.S. 562 (2000); Engquist v. Oregon Dep't of Agric., 128 S. Ct. 2146 (2008); see Robert C. Farrell, The Equal Protection Class of One Claim: Olech, Enquist, and the Supreme Court's Misadventure, 61 S.C. L. REV. 107 (2009); William D. Araiza, Constitutional Rules and Institutional Roles: The Fate of the Equal Protection Class of One and What It Means for Congressional Power to Enforce Constitutional Rights, 62 SMU L. REV. 27 (2009).

17. Snowden v. Hughes, 321 U.S. 1 (1944) (holding that not every denial of a right conferred by state law involves a denial of the equal protection of the laws but that the improper application of a legal rule may violate equal protection where there is shown to be present an element of intentional or purposeful discrimination). 
the overall validity of a classification, and affirmative action claims are always of this type, appeals to the individual or personal nature of equal protection are never relevant to the ultimate decision in a case.

\section{THE SUPREME COURT PRECEDENTS ON EQUALITY AS A LIMIT ON GOVERNMENTAL CLASSIFICATION}

From its earliest post-Civil War cases to the present, when the United States Supreme Court has decided cases arising under the Equal Protection Clause of the Fourteenth Amendment or its Fifth Amendment counterpart, ${ }^{18}$ it has treated the Equal Protection Clause as a limitation on government classification and nothing more. ${ }^{19}$ During this entire period, the Supreme Court's equal protection cases have either ignored an individual rights view of equal protection, reached results that were inconsistent with (and therefore implicitly rejected) an individual rights view of equal protection, or confronted the individual rights view directly and rejected it. This section examines this history.

\section{A. The Supreme Court's Early Cases on Racial Classifications}

In Strauder v. West Virginia ${ }^{20}$ which was decided in 1879 and is one of the earliest Supreme Court cases construing the Equal Protection Clause, the Court invalidated a West Virginia statute that limited juror service to white men. Identifying "the one pervading purpose" 21 of the Equal Protection Clause, and citing the Slaughter-House Cases, the Court noted that "The existence of laws in the States where the newly emancipated Negroes resided, which discriminated with gross injustice and hardship against them as a class, was the evil to be remedied, and by it [the Fourteenth Amendment] such laws were forbidden." 22 The Court further confirmed this class-based notion of equal protection when it said, "We doubt very much whether any action of a

18. The Equal Protection Clause of the Fourteenth Amendment applies only against the states. The Fifth Amendment applies against the federal government, but it does not contain an equal protection clause. The Supreme Court has resolved this problem by finding an implied equal protection component within the Fifth Amendment's Due Process Clause. See Bolling v. Sharpe, 347 U.S. 497, 498-99 (1954); Adarand Constructors, Inc. v. Pena, 515 U.S. 200, 224 (1995).

19. See infra Sections II.A-E.

20. Strauder v. West Virginia, 100 U.S. 303 (1879) (abrogated by Taylor v. Louisiana, 419 U.S. 522 (1975))

21. Id. at 307.

22. Id. (emphasis added). 
state, not directed by way of discrimination against the negroes, as a class, will ever be held to come within the purview of this provision." ${ }^{23}$ The Court's prediction that the Equal Protection Clause would be limited to racial classifications turned out to be incorrect. In fact, the Clause has become a general equality principle, affecting all kinds of classifications. The Court's insight, however, that the equality principle embedded in the Equal Protection Clause was concerned with government classifications turned out to be entirely correct.

Just a few years later, in 1886, the Court decided Yick Wo v. Hopkins, ${ }^{24}$ a case that involved a racially neutral city ordinance that required those who operated laundries in wooden buildings to get a written permit. This facially neutral law, however, was not administered in a neutral way. Of the more than two hundred applicants of Chinese ancestry, all were denied permits. ${ }^{25}$ Of all the applicants who were not Chinese, all but one received permits. ${ }^{26}$ The Court found that this unequal administration of a neutral ordinance was a violation of the Equal Protection Clause. Even though the ordinance itself was not drawn up on the basis of a racial classification, the manner in which the ordinance was administered was proof of discrimination against a class. The Court explained, "the facts shown establish an administration directed so exclusively against a particular class of persons as to warrant and require the conclusion that, whatever may have been the intent of the ordinances as adopted, they are applied by the public authorities charged with their administration ... with a mind so unequal and oppressive as to amount to a practical denial by the state of that equal protection of the laws. ${ }^{27}$ In this case, the individual acts of discrimination against particular individuals became, over time, a pattern of discrimination against a class of persons, and it was discrimination against this class that the Court considered a violation of equal protection.

In 1896, in Plessy v. Ferguson, ${ }^{28}$ the Supreme Court upheld a Louisiana statute that required railroad companies to provide "equal but separate accommodations for the white and colored races." 29 The plaintiff's challenge was to the racial classification explicitly set forth in a statute. The Court, in

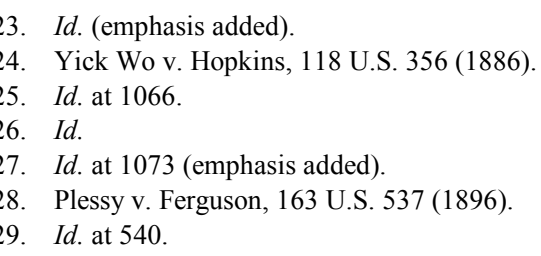


noting that "[t]he object of the[ Fourteenth Amendment] was undoubtedly to enforce the absolute equality of the two races before the law," 30 adopted a view of the Equal Protection Clause that was quite consistent with that in the two previous cases that the clause limits racial classifications, and no more. The Court explained that the exercise of the police power must be reasonable and "extend only to such laws as are enacted in good faith for the promotion of the public good, and not for the annoyance or oppression of a particular class." 31 The Plessy Court then went on to uphold the state-mandated segregation of railroad cars. For our purposes here, however, the point is that the Court applied the Equal Protection Clause as a limitation on classifications, with no concern for the individual complainant.

\section{B. In the Wilderness: The Supreme Court's Early Rational Basis Cases}

During the first four decades of the twentieth century, the Court did not decide any equal protection cases that have become significant precedents. It was during this time that Justice Holmes could legitimately characterize equal protection claims as "the usual last resort of constitutional arguments." 32 However, it was in this same period that, quietly and under the radar, the Supreme Court decided a number of equal protection cases that, if not well known today, did establish the rational basis framework as a standard of review and also made clear that the Court understood that the work of the Equal Protection Clause was to limit the use of classifications.

In 1899, in Atchison, Topeka, \& Santa Fe Railroad Co. v. Matthews, ${ }^{33}$ the Court considered a Kansas statute that singled out railroad companies for special, unfavorable treatment. The companies were liable for all fires they caused, even without proof of negligence, and plaintiffs bringing successful actions against them could recover attorneys' fees. ${ }^{34}$ The Court, upholding the statute against an equal protection challenge, noted that the state, when exercising its police power "to promote the health, peace, morals, education, and good order of the people," affect different groups differently:

30. Id. at 544 .

31. Id. at 550 (emphasis added).

32. Buck v. Bell, 274 U.S. 200, 208 (1927).

33. Atchison, Topeka, \& Santa Fe R.R. v. Matthews, 174 U.S. 96 (1899).

34. Id. at 97.

35. Id. at 103 . 
The equal protection of the laws which is guaranteed by the fourteenth amendment does not forbid classification. ... Special burdens are often necessary for general benefits - for supplying water, preventing fires, lighting districts, cleaning streets, opening parks, and many other objects. Regulations for these purposes may press with more or less weight upon one than upon another, but they are designed, not to impose unequal or unnecessary restrictions upon anyone, but to promote with as little inconvenience as possible, the general good. . . . This declaration has, in various language, been often repeated, and the power of classification upheld, whenever such classification proceeds upon any difference which has a reasonable relation to the object sought to be accomplished. ${ }^{36}$

Later in the opinion, the Court made explicit the relationship between classification and equality: "It is the essence of a classification that upon the class are cast duties and burdens different from those resting on the general public." 37 The Court conceded that, under the Kansas statute, railroad companies were not treated the same as other litigants, yet "this inequality of right in the courts is of no significance upon the question of constitutionality. Indeed, the very idea of classification is that of inequality." 38

Atchison is important for two reasons. First, it is an early recognition by the Supreme Court that equality claims in the courts are typically challenges to classifications. Second, it establishes the standard that has become modern day rational basis review - that a classification will be sustained under the Equal Protection Clause if it "proceeds upon any difference which has a reasonable relation to the object sought to be accomplished." 39

Three years later, in 1902, in Connolly v. Union Sewer Pipe Co. ${ }^{40}$ the Court invoked the Equal Protection Clause to invalidate an Illinois antitrust statute. The statute exempted from its general antitrust provisions "agricultural products or live stock while in the hands of the producer or raiser," ${ }^{, 4}$ and the Court found that this exemption was fatal to the statute. ${ }^{42}$ The Court found that those covered by the statute, persons engaged in the trade or sale of commodities, were no different from those exempted, those who raised and sold their own agricultural products or live stock. ${ }^{43}$ The Court explained the equal protection problem as one of classification:

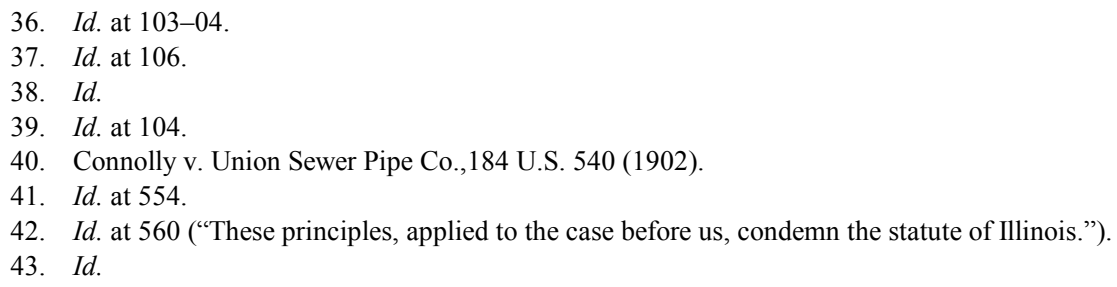


The difficulty is not met by saying that, generally speaking, the state when enacting laws may, in its discretion, make a classification of persons, firms, corporations, and associations, in order to subserve public objects. For this court has held that classification must always rest upon some difference which bears a reasonable and just relation to the act in respect to which the classification is proposed, and can never be made arbitrarily and without any such basis.... But arbitrary selection can never be justified by calling it classification. The equal protection demanded by the 14th Amendment forbids this. ... . No duty rests more imperatively upon the courts than the enforcement of those constitutional provisions intended to secure that equality of rights which is the foundation of free government. . . It is apparent that the mere fact of classification is not sufficient to relieve a statute from the reach of the equality clause of the 14th Amendment, and that in all cases it must appear, not only that a classification has been made, but also that it is one based upon some reasonable ground, some difference which bears a just and proper relation to the attempted classification, and is not a mere arbitrary selection. ${ }^{44}$

Once again, the Court determined that the equal protection issue was one of classification.

One year later, in 1903, the Court in Billings v. Illinois ${ }^{45}$ upheld an Illinois inheritance statute challenged under the Equal Protection Clause for its differing treatment of life estates. The statute taxed life estates where the remainder was to lineal heirs but did not tax similar life estates when the remainder was to collateral heirs or strangers to the blood. ${ }^{46}$ The challenge to the statute was that "[1]ife tenants constitute but a single class," ultimate vesting of the remainder interest should not affect the taxability of the underlying life estate, all of which, the argument went, should be treated the same. The Court viewed the problem as one of classification:

If there had been a proper classification there could not have been the denial of the equal protection of the laws ... We said it was established by cases that classification must be based on some reasonable ground. It could not be a mere arbitrary selection. But what is the test of an arbitrary selection? It is difficult to exhibit it precisely in a general rule. Classification is essentially the same in law as it is in other departments of knowledge or practice. It is the grouping of things in speculation or practice because they agree with one another in certain particulars and differ from other things in those same particulars. Things may have very diverse qualities, and yet be united in a class. They may have very similar qualities, and yet be cast in different classes. Cattle and horses may be considered in a class for some purposes. Their differences are certainly pronounced. Salt and sugar may be associated in a grocer's stock for a grocer's purposes. To confound them in use would be very disappointing. Human beings are essentially alike, yet some

\footnotetext{
44. Id. at 560-61.

45. Billings v. Illinois, 188 U.S. 97 (1903).

46. Id. at 99,101 .

47. Id. at 103 .
} 
individuals may have attributes or relations not possessed by others, which may constitute them a class. But their classification - indeed, all classification-must primarily depend upon purpose - the problem presented.... If the purpose is within the legal powers of the legislature, and the classification made has relation to that purpose (excludes no persons or objects that are affected by the purpose, includes all that are), logically speaking, it will be appropriate; legally speaking, a law based upon it will have equality of operation. ${ }^{48}$

The Court upheld the different treatment of life estates based on who would succeed to the remainder as an appropriate use of the state's power to classify and to make reasonable distinctions between lineal and collateral relatives in specifying the rules for transfer and devolution of property.

In 1911, in Linsley v. Natural Carbonic Gas Co. ${ }^{49}$ the Court reviewed a New York statute that regulated the extraction of mineral waters. The statute prohibited the pumping of water from wells bored or drilled into rock but not from wells that did not penetrate the rock. ${ }^{50}$ In rejecting a claim that this was an arbitrary classification in violation of the Equal Protection Clause, the Court explained:

The rules by which this contention must be tested, as is shown by repeated decisions of this court, are these: 1 . The equal-protection clause of the 14th Amendment does not take from the state the power to classify in the adoption of police laws, but admits of the exercise of a wide scope of discretion in that regard, and avoids what is done only when it is without any reasonable basis, and therefore is purely arbitrary. 2. A classification having some reasonable basis does not offend against that clause merely because it is not made with mathematical nicety, or because in practice it results in some inequality. 3. When the classification in such a law is called in question, if any state of facts reasonably can be conceived that would sustain it, the existence of that state of facts at the time the law was enacted must be assumed. 4. One who assails the classification in such a law must carry the burden of showing that it does not rest upon any reasonable basis, but is essentially arbitrary. ${ }^{51}$

Once again, this is a clear-cut expression of the Court's view that the Equal Protection Clause works as a limit on governmental classifications, and nothing more. Numerous other Supreme Court decisions from this period stand for the same proposition. ${ }^{52}$

48. Id. at $101-03$.

49. Lindsley v. Natural Carbonic Gas Co., 220 U.S. 61 (1911).

50. Id. at 78 .

51. Id. at 78-79.

52. E.g., N.Y. Rapid Transit Corp. v. City of New York, 303 U.S. 573 (1938); Louisville Gas \& Elec. Co. v. Coleman, 277 U.S. 32 (1928); F.S. Royster Guano Co. v. Virginia, 253 U.S. 412 (1920); Jeffrey Mfg. Co. v Blagg, 235 U.S. 571 (1915). 
In two cases during this period, the Court not only spoke of equal protection as a limit on classification, but quite directly rejected the view that it could be concerned with individual circumstances. In the first of these, Ozan Lumber v. Union County National Bank ${ }^{53}$ in 1907, the Court considered an Arkansas statute that regulated the collection of promissory notes but exempted from its coverage merchants and dealers who sold patented things in the usual course of business. ${ }^{54}$ In rejecting the argument that other people ought also to have been included within the exemption, the Court explained:

Exceptional and rare cases, not arising out of the sale of patented things in the ordinary way, may be imagined where this general classification separating the merchants and dealers from the rest of the people might be regarded as not sufficiently comprehensive, because in such unforeseen, unusual, and exceptional cases the people affected by the statute ought, in strictness, to have been included in the exception. . . . But we do not think the statute should be condemned on that account. It is because such imaginary and unforeseen cases are so rare and exceptional as to have been overlooked that the general classification ought not to be rendered invalid. In such case there is really no substantial denial of the equal protection of the laws within the meaning of the $[\mathrm{A}]$ mendment. . . . It is almost impossible, in some matters, to foresee and provide for every imaginable and exceptional case, and a legislature ought not to be required to do so at the risk of having its legislation declared void, although appropriate and proper upon the general subject upon which such legislation is to act, so long as there is no substantial and fair ground to say that the statute makes an unreasonable and unfounded general classification, and thereby denies to any person the equal protection of the laws. In a classification for governmental purposes there cannot be an exact exclusion or inclusion of persons and things. ${ }^{55}$

The Court thus found that the exemption of certain classes did not violate the Equal Protection Clause. In doing so, the Court was quite explicit that, so long as a classification satisfies the requirement of reasonableness, there is no constitutional problem if the classification fails to account for the "exceptional and rare cases," or the "unforeseen, unusual, and exceptional cases." Nor is it a constitutional problem if the classification fails to provide "an exact exclusion or inclusion of persons or things." It is not possible to reconcile this early statement from the Supreme Court with a view that the Equal Protection Clause protects individual rights.

In Colgate v. Harvey ${ }^{56}$ in 1935, the second of the cases rejecting an individual rights view of equal protection, the Court considered a Vermont

53. Ozan Lumber Co. v. Union County Nat'l Bank, 207 U.S. 251 (1907).

54. Id. at $253-54$

55. Id. at 256 .

56. Colgate v. Harvey, 296 U.S. 404 (1935). 
income tax statute that provided a personal exemption for certain interest and dividends issued by corporations incorporated in Vermont, but not for interest and dividends issued by out-of-state corporations. ${ }^{57}$ In upholding the statute under the Equal Protection Clause, the Court explained:

\begin{abstract}
It is settled beyond the admissibility of further inquiry that the equal protection clause of the Fourteenth Amendment does not preclude the states from resorting to classification for the purposes of legislation .... But the classification must be reasonable, not arbitrary, and must rest upon some ground of difference having a fair and substantial relation to the object of the legislation, so that all persons similarly circumstanced shall be treated alike. ${ }^{58}$

The question of equal protection must be decided in respect of the general classification rather than by the chance incidence of the tax in particular instances or with respect to particular taxpayers. "And inequalities that result not from hostile discrimination, but occasionally and incidentally in the application of a system that is not arbitrary in its classification, are not sufficient to defeat the law." ... The operation of a general rule will seldom be the same for everyone. If the accidents of trade lead to inequality or hardship, the consequences must be accepted as inherent in government by law instead of government by edict. ${ }^{59}$
\end{abstract}

This opinion makes clear that the adverse effects of a rule "in particular instances or with respect to particular taxpayers" is not relevant to the validity of a rule under the Equal Protection Clause so long as the classification is reasonable.

\title{
C. The Supreme Court's Equal Protection Fundamental Rights Cases
}

Beginning in 1942 with Skinner v. Oklahoma, ${ }^{60}$ the Court created a line of fundamental rights precedents under the Equal Protection Clause. These cases make clear that equal protection is not about the protection of individual rights. In Skinner, the Court reviewed an Oklahoma statute under which a person convicted three times of felonies involving moral turpitude could be sterilized, but with some exceptions. ${ }^{61}$ If the case were to arise for the first time today, after the Court's Griswold, ${ }^{62}$ Eisenstadt, ${ }^{63}$ and $R o e^{64}$ trilogy, it would clearly be a substantive due process case, in as much as the term

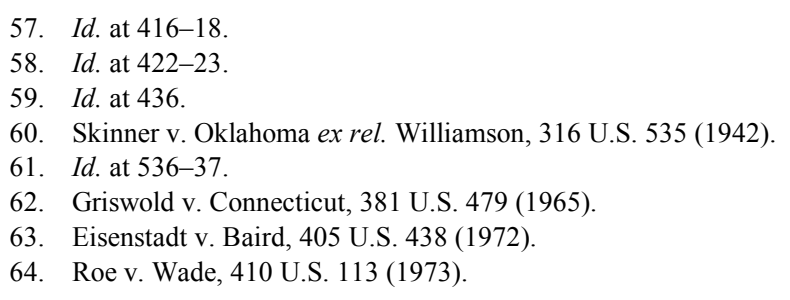


"liberty" in the Due Process Clause encompasses a right of privacy that includes within it matters of procreation, marriage, and the decision whether "to bear or beget a child." ${ }^{65}$ If Skinner had been thus decided, there would have been no need to compare the petitioner's situation with others who might be similar; one need only make the point that the statute directly interferes with an implied fundamental right of a specific individual, and therefore it must be justified under the strict scrutiny standard. The Court, however, in 1942 , was justifiably reluctant to engage in such substantive due process reasoning because, just five years earlier, in West Coast Hotel Co. v. Parrish, ${ }^{66}$ it had overruled Adkins v. Children's Hospital, ${ }^{67}$ and with it the view of the Constitution under which state regulation of contracts was viewed as an interference with the "liberty of contract" that is part of the Due Process Clause ${ }^{68}$ Thus, for the Court, it made sense to decide the case on the basis of equal protection, a narrower ground under which the Court could prohibit application of the sterilization statute to a select subgroup without having to invalidate the entire statute as in interference with a constitutionally protected liberty interest.

Once, however, the Skinner Court determined to decide the case on equal protection grounds, it immediately turned away from a focus on the plight of the individual petitioner and focused instead on how the statute created two classes that had to be treated similarly. Specifically, the Court noted that the statute provided for sterilization of three-time felons who had committed larceny but exempted three-time felons who had embezzled. ${ }^{69}$ The Court noted that "the nature of the two crimes is intrinsically the same and [ignoring the sterilization statute] they are punishable in the same manner." ${ }^{.70}$ The Court had now identified two classes that it could compare for equal protection purposes. In terms of the level of scrutiny to be applied to this classification, the Court insisted, "strict scrutiny of the classification which a state makes in a sterilization law is essential, lest unwittingly or otherwise, invidious discriminations are made against groups or types of individuals in violation of the constitutional guarantee of just and equal laws." ${ }^{, 71}$ Thus, once the

65. Roe, 410 U.S. at 169-70; Eisenstadt, 405 U.S. at 453.

66. West Coast Hotel Co. v. Parrish, 300 U.S. 379 (1937).

67. Adkins v. Children's Hosp., 261 U.S. 525 (1923).

68. This is the view famously associated with Lochner v. New York, 198 U.S. 45 (1905).

69. Skinner, 316 U.S. at 538-39.

70. Id. at 539 .

71. Id. at 541 . 
Skinner Court determined that it would decide the case on the grounds of equal protection, it turned to the task of finding and comparing classes.

The Skinner Court's discussion of the appropriate remedy for the equal protection violation is also instructive on the issue of individual rights. If the Court's decision had been based on the individual right to privacy under the Due Process Clause, then the remedy to vindicate that individual right would have been the prohibition of sterilizing the individual petitioner. Since, however, the case had been decided as involving an inappropriate classification under the Equal Protection Clause, the Court explained that "It is by no means clear whether ... this particular constitutional difficulty might be solved by enlarging on the hand or contracting on the other ... the class of criminals who might be sterilized." 72 This somewhat cryptic comment suggests that the individual petitioner's concerns carry no weight here. The state was still free to sterilize him as long as it was also willing to sterilize all other three-time felons, that is, as long as it has made an appropriate classification. Or, as the Court explained in a subsequent case, when an equality argument succeeds, "the appropriate remedy is a mandate of equal treatment, a result that can be accomplished by withdrawal of benefits from the favored class as well as by extension of benefits to the excluded class." ${ }^{, 73}$

Thirty-six years after Skinner, the Court in Zablocki v. Redhail ${ }^{74}$ engaged in a similar kind of equal protection fundamental rights reasoning that once again demonstrated that equal protection arguments are concerned with classifications, not with protecting individual rights. In Zablocki, the Court invalidated a Wisconsin statute under which the state would not grant a marriage license to an applicant who had an outstanding child support order unless the applicant received permission from a court. ${ }^{75}$ As in Skinner, the more obvious way for the Court to decide Zablocki was as a substantive due process case, since the statute infringed on the implied fundamental right to marry. If the Court had followed this route, the only issues would have been the individual harm to the appellee Redhail, and whether or not the state could justify its interference with his right to marry as narrowly tailored to achieve a compelling interest. The Court, however, decided to treat the case as arising under the Equal Protection Clause, ${ }^{76}$ and therefore needed to identify a

72. Id. at 543 (internal citation omitted).

73. Heckler v. Mathews, 465 U.S. 728, 740 (1984) (emphasis omitted) (citing Iowa-Des Moines Nat'l Bank v. Bennett, 284 U.S. 239, 247 (1931)).

74. Zablocki v. Redhail, 434 U.S. 374 (1978).

75. Id. at 375 .

76. Id. at $382-83$. 
classification that would trigger equal protection analysis. The Court identified the disadvantaged class as a certain class of Wisconsin residents who may not marry. The Court explained that the "class is defined by the statute to include any "Wisconsin resident having minor issue not in his custody and which he is under an obligation to support by any court order or judgment." $" 77$ The Court then went on to explain the kind of analysis that is required when one challenges a statute under the Equal Protection Clause:

\begin{abstract}
In evaluating [the Wisconsin statute] under the Equal Protection Clause, "we must first determine what burden of justification the classification created thereby must meet, by looking at the nature of the classifications and the individual interests affected." . . . Since our past decisions make clear that the right to marry is of fundamental importance, and since the classification at issue here significantly interferes with the exercise of that right, we believe that "critical examination" of the state interests advanced in support of the classification is required. ${ }^{78}$
\end{abstract}

The Court then noted that under the statute "no Wisconsin resident in the affected class may marry in Wisconsin or elsewhere without a court order." 79 The Court then determined that the state-created classification it had identified did not meet the equal protection requirement of strict scrutiny and invalidated the statute. ${ }^{80}$

Justice Stewart concurred in the result in Zablocki, but he was unable to join in the majority opinion. Stewart's concurrence was intended as a critique of the majority's equal protection analysis, but it also serves as a clear statement of the distinction between the Equal Protection Clause, which limits government classifications, and substantive due process, which protects individual rights. According to Stewart:

I cannot join the opinion of the Court. To hold, as the Court does, that the Wisconsin statute violates the Equal Protection Clause seems to me to misconceive the meaning of that constitutional guarantee. The Equal Protection Clause deals not with substantive rights or freedoms but with invidiously discriminatory classifications.... The paradigm of its violation is, of course, classification by race. . . . Like almost any law, the Wisconsin statute now before us affects some people and does not affect others. But to say that it thereby creates "classifications" in the equal protection sense strikes me as little short of fantasy. The problem in this case is not one of discriminatory classifications, but of unwarranted encroachment upon a constitutionally protected freedom. I think that the Wisconsin statute is unconstitutional because it exceeds the bounds of permissible state regulation of

77. Id. at 375 (quoting WiS. STAT. § 245.10 (1973)).

78. Id. at 383 (internal citations omitted).

79. Id. at 387 (emphasis added).

80. Id. at $388-91$. 
marriage, and invades the sphere of liberty protected by the Due Process Clause of the Fourteenth Amendment. ${ }^{81}$

Stewart's critique makes clear that, to him, what was really at stake in Zablocki was an individual, fundamental right to marry and that the proper analysis for the Court should have been that part of the Fourteenth Amendment that actually protects individual rights, the Due Process Clause. Stewart forthrightly concedes that, if one is to make an equal protection argument, the identification of a class is essential. There was, however, no need in Zablocki to identify a class and therefore neither need nor grounds for equal protection reasoning.

The Court has also decided a series of cases involving access to the courts as a fundamental right. In these cases, the Court has made use of both equal protection and due process reasoning and has identified the difference between them. Thus, in Griffin v. Illinois, ${ }^{82}$ the Court held that an indigent defendant had a right under some combination of due process and equal protection to have a trial transcript provided at no charge for his appeal of his conviction. In Douglas v. California, ${ }^{83}$ the Court held, again as a matter of due process and equal protection, that an indigent defendant was entitled as of right to appointment of counsel for his first appeal. In Ross v. Moffitt ${ }^{84}$ the Court determined that the right to appointment of counsel on appeal did not extend to discretionary state appeals. In reaching this result, the Ross Court explained the difference between due process and equal protection that was implicit in its earlier decisions:

The precise rationale for the Griffin and Douglas lines of cases has never been explicitly stated, some support being derived from the Equal Protection Clause of the Fourteenth Amendment, and some from the Due Process Clause of that Amendment. Neither Clause by itself provides an entirely satisfactory basis for the result reached, each depending on a different inquiry which emphasizes different factors. "Due process" emphasizes fairness between the State and the individual dealing with the State, regardless of how other individuals in the same situation may be treated. "Equal protection," on the other hand, emphasizes disparity in treatment by a State between classes of individuals whose situations are arguably indistinguishable. ${ }^{85}$

81. Id. at 391-92 (Stewart, J., concurring).

82. Griffin v. Illinois, 351 U.S. 12 (1956).

83. Douglas v. California, 372 U.S. 353 (1963).

84. Ross v. Moffitt, 417 U.S. 600 (1974).

85. Id. at $608-09$ (internal citations omitted). 
Here, the Court made it very clear that due process protects the individual, without any comparison of the state's treatment of other individuals, while equal protection looks only at the disparity of treatment between "classes of individuals" who are similarly situated. Subsequent cases from the Supreme Court confirmed this distinction. ${ }^{86}$

\section{Cases Implicitly Rejecting the Individual Rights Version of Equal Protection}

The U.S. Supreme Court is committed to the view of equal protection as a limit on governmental classification to such an extent that it usually feels no need to explicitly address, and then reject, the individual rights view. In some cases, the result the Court reaches is inconsistent with an individual rights view and thus these cases stand as an implicit rejection of that view. This section examines two cases of that type, where the Court showed no concern for the unfairness to an individual that resulted from its equal protection analysis.

Massachusetts Board of Retirement v. Murgia ${ }^{87}$ is a particularly clear expression of the view that equal protection is a limit on classification rather than a protector of individual rights. In that case, the Court reviewed a Massachusetts statute requiring all state police officers to retire at age fifty. ${ }^{88}$ The purpose of the law was to promote public safety "by assuring physical preparedness of its uniformed police." ${ }^{" 89}$ Robert Murgia, the plaintiff in the case, was more than fifty years of age, but extremely fit. In fact, "Murgia had passed [a rigorous physical] examination four months before he was retired, and there is no dispute that, when he retired, his excellent physical and mental health still rendered him capable of performing the duties of a uniformed officer." 90 A basic sense of fairness or a concern with individual rights suggests that Murgia, who was extremely fit, ought not to be disadvantaged by a rule whose purpose was to weed out unfit police officers. Was not Murgia, a physically fit police officer, similarly situated to the other

86. E.g., Evitts v. Lucey, 469 U.S. 387, 405 (1985) (citing Ross, 417 U.S. at 609). Bearden v. Georgia, 461 U.S. 660, 665 (1983) ("[W] generally analyze the fairness of relations between the criminal defendant and the State under the Due Process Clause, while we approach the question of whether the State has invidiously denied one class of defendants a substantial benefit available to another class of defendants under the Equal Protection Clause.").

87. Mass. Bd. of Ret. v. Murgia, 427 U.S. 307 (1976).

88. Id. at 308

89. Id. at 314 .

90. Id. at 311 . 
physically fit, but younger, police officers in relation to the purpose of assuring a fit police force?

From the individual perspective of Murgia himself, that claim makes sense, but it fails when Murgia's individual claim is confronted with, and overridden by, a reasonable classification. In fact, the Supreme Court, in deciding Murgia, was not concerned with Murgia's individual situation, but rather with the reasonableness of the classification that assumed that those over fifty were less fit than those under fifty. ${ }^{91}$ Once the Court determined that physical fitness tends to decline with age, ${ }^{92}$ that was the end of the matter. Since there was some correlation between age and fitness, ${ }^{93}$ that was all that the Equal Protection Clause required. As long as a classification is reasonable, it does not matter that the generalization embodied in the classification is not true as to a particular member of the class. In this context, it is not true that equal protection is a personal, individual right.

Nordlingerv. Hahn ${ }^{94}$ is another case in which the Supreme Court ignored the view that the Equal Protection Clause protects individual rights. In that case, the petitioner, Stephanie Nordlinger, challenged California's Proposition 13 , a state constitutional provision that required property to be assessed for tax purposes at its acquisition value, with a small allowance for inflation..$^{95}$ The effect of this provision, over a period of time during which there was substantial inflation in the housing market, was that long-time homeowners owed property taxes that were much lower than the taxes of their neighbors who had moved in more recently. Nordlinger was paying property taxes about five times as high as a neighbor with a house of identical size on a slightly larger lot. ${ }^{96}$ There were other, even more extreme disparities, including one where the purchaser of a home was required to pay taxes seventeen times higher than those his seller had been paying. ${ }^{97}$ To one uninitiated in the ways of equal protection or committed to an individual rights view of equal protection, these differences might appear to present an easy case of inequality. Nordlinger claimed that she was similarly situated to her neighbor with the identical house and therefore should be charged the same amount in

91. Id. at 314 .

92. Id. at 315 .

93. Id. at 311 ("[T] he testimony clearly established that the risk of physical failure, particularly in the cardiovascular system, increases with age, and that the number of individuals in a given age group incapable of performing stress functions increases with the age of the group.").

94. Nordlinger v. Hahn, 505 U.S. 1 (1992).

95. Id. at 5.

96. Id. at 7 .

97. Id. at n.2. 
property taxes. That, however, was not how the Court viewed the case. The treatment of the individual Stephanie Nordlinger was irrelevant. What mattered was the reasonableness of the classification that treated newer and long-term owners differently.

The Court was quite clear that the test was one of reasonableness of classification and nothing more. Here is how the Court explained the demand of equal protection:

\begin{abstract}
The Equal Protection Clause of the Fourteenth Amendment, $\S 1$, commands that no State shall "deny to any person within its jurisdiction the equal protection of the laws." Of course, most laws differentiate in some fashion between classes of persons. The Equal Protection Clause does not forbid classifications. It simply keeps governmental decisionmakers from treating differently persons who are in all relevant respects alike. ... As a general rule, "legislatures are presumed to have acted within their constitutional power despite the fact that, in practice, their laws result in some inequality." .. . Accordingly, this Court's cases are clear that, unless a classification warrants some form of heightened review because it jeopardizes exercise of a fundamental right or categorizes on the basis of an inherently suspect characteristic, the Equal Protection Clause requires only that the classification rationally further a legitimate state interest. ${ }^{98}$
\end{abstract}

The Court then determined that the classification that treated older and newer homeowners differently was rationally related to two state interests (1) local neighborhood preservation, continuity, and stability, and (2) protecting the reliance interest of existing owners in their existing property tax level. ${ }^{99}$ The majority opinion did not even feel the need to address the individual concerns of Stephanie Nordlinger, who was paying five times the taxes of her long-term neighbors. It was only Justice Stevens, in dissent, who seemed at all concerned with the unfairness to the individual. Stevens cited a report from a California Senate Commission, "The inequity is clear. One young family buys a new home and is assessed at full market value. Another young family inherits its home, but pays taxes based on the parents' date of acquisition even though both homes are of identical value."100 However, Stevens' concerns were irrelevant to the majority. The individual harm to Stephanie Nordlinger was not part of the equal protection calculus so long as that harm was the result of a reasonable classification.

98. Id. at 10 .

99. Id. at $12-13$.

100. Id. at 30 (Stevens, J., dissenting) (quoting CAL. State S. RePORT OF SENATE COMMISSION ON PRoperty TAX EQUity AND REVENUE, at 9-10 (1991)). 


\section{E. Cases Explicitly Rejecting the Individual Rights Version of Equal Protection}

This section considers three cases in which the Court has explicitly considered an individual rights version of equal protection and then rejected it.

In Weinberger v. Salfi, ${ }^{101}$ the Court considered a challenge to a provision of the Social Security Act under which surviving wives and stepchildren could not qualify for survivors benefits if the wife's marriage to the covered worker had taken place fewer than nine months before his death. ${ }^{102}$ The purpose of the rule was to weed out sham marriages, that is, those entered into solely for the purpose of qualifying for survivors' benefits. ${ }^{103}$ When appellee Salfi married her husband, he was in apparent good health but died of a heart attack less than a month later. ${ }^{104}$ The Court was willing to concede that the statute would exclude "some surviving wives who married with no anticipation of shortly becoming widows" and that Mrs. Salfi might be among that group. ${ }^{105}$ That did not matter. Such a concern with Mrs. Salfi's individual situation would suggest that the Equal Protection Clause protects individuals. The Court was quite specific in rejecting that argument since the proper measure of review was whether or not the classification satisfied the standards of "legislative reasonableness":

\footnotetext{
Under those standards, the question raised is not whether a statutory provision precisely filters out those, and only those, who are in the factual position which generated the congressional concern reflected in the statute. Such a rule would ban all prophylactic provisions, and would be directly contrary to our holding in [Mourning v. Family Publications]. Nor is the question whether the provision filters out a substantial part of the class which caused congressional concern, or whether it filters out more members of the class than nonmembers. The question is whether Congress, its concern having been reasonably aroused by the possibility of an abuse which it legitimately desired to avoid, could rationally have concluded both that a particular limitation or qualification would protect against its occurrence, and that the expense and other difficulties of individual determinations justified the inherent imprecision of a prophylactic rule. We conclude that the duration of relationship test meets this constitutional standard. ${ }^{106}$
}

101. Weinberger v. Salfi, 422 U.S. 749 (1975).

102. Id. at $754-55$.

103. Id. at 767 .

104. Id. at 753 .

105. Id. at 781 .

106. Id. at 777 . 
The Court then went on specifically to differentiate this deferential equal protection standard with the liberty-protecting, individual-rights-oriented due process standard. The Court explained:

\begin{abstract}
The Constitution does not preclude such policy choices as a price for conducting programs for the distribution of social insurance benefits. . . . Unlike criminal prosecutions, or the custody proceedings at issue in Stanley v. Illinois, such programs do not involve affirmative Government action which seriously curtails important liberties cognizable under the Constitution. There is thus no basis for our requiring individualized determinations when Congress can rationally conclude not only that generalized rules are appropriate to its purposes and concerns, but also that the difficulties of individual determinations outweigh the marginal increments in the precise effectuation of congressional concern which they might be expected to produce. ${ }^{107}$
\end{abstract}

As the Court explained, any interpretation of the Equal Protection Clause that was more protective of individual rights would be "a virtual engine of destruction for countless legislative judgments which have heretofore been thought to be wholly consistent with the Fifth and Fourteenth Amendments to the Constitution." 108

What did this mean for Mrs. Salfi? Her personal situation was of no concern to the Court. It might well have been true that she had fallen in love with her husband and had given no thought to eligibility for Social Security benefits, and thus was in the truest sense a "spouse" to her husband. She was, however, for Social Security purposes, a gold digger who had entered into a sham marriage to qualify for benefits. Under the Equal Protection Clause, her actual individual circumstances were irrelevant.

In Parham v. Hughes, ${ }^{109}$ the Court, in a plurality opinion, considered the constitutionality of a Georgia statute under which the mother of an illegitimate child could sue for the wrongful death of the child but a father who had not legitimated a child could not. ${ }^{110}$ The Court treated the statute as involving classifications based on gender and illegitimacy and determined that the statute did not violate the Equal Protection Clause. According to the Court:

The fact is that mothers and fathers of illegitimate children are not similarly situated. Under Georgia law, only a father can by voluntary unilateral action make an illegitimate child legitimate. Unlike the mother of an illegitimate child whose identity will rarely be in doubt, the identity of the father will frequently be unknown. . . By

107. Id. at 785 .

108. Id. at 772 .

109. Parham v. Hughes, 441 U.S. 347 (1979) (plurality opinion).

110. Id. at 348-49. 
coming forward with a motion under [the statute], however, a father can both establish his identity and make his illegitimate child legitimate. ${ }^{111}$

The Court claimed that the different treatment of mothers and fathers in terms of bringing wrongful death actions was not in fact a gender classification but rather a distinction "between fathers who have legitimated their children and those who have not." 112 The Court then found that this distinction was rationally related to the state's legitimate interest in avoiding fraudulent claims of paternity and therefore the statute did not violate the Equal Protection Clause. ${ }^{113}$

But what about the fact that "[t]he appellant was the biological father of Lemuel Parham," 114 the minor child who was killed in the automobile collision? Even though it might be reasonable for the state to make generalizations that distinguished between fathers who had in fact legitimated their children and men who only claimed to be the father after the child's death, that distinction had nothing to do with the actual facts of Curtis Parham's life. Therefore, the appellant argued "that whatever may be the problem with establishing paternity generally, there is no question in this case that he is the father." 115 The Court's responded by explaining that the individual circumstances of Parham's life were irrelevant to the equal protection claim. According to the Court:

This argument misconceives the basic principle of the Equal Protection Clause. The function of that provision of the Constitution is to measure the validity of classifications created by state laws. Since we have concluded that the classification created by the Georgia statute is a rational means for dealing with the problem of proving paternity, it is constitutionally irrelevant that the appellant may be able to prove paternity in another manner. ${ }^{116}$

Perhaps the Court's strongest rejection of an individual rights view of equal protection is its decision in Kimel v. Florida Board of Regents. ${ }^{117}$ In Kimel, the Court was concerned with the limits of Congressional power to enforce the Fourteenth Amendment through appropriate legislation. The particular issue before the Court was whether Congress had the power under

111. Id. at $355-56$.

112. $I d$. at 356 .

113. Id. at $357-58$.

114. Id. at 349 .

115. Id. at 358

116. $I d$.

117. Kimel v. Florida Bd. of Regents, 528 U.S. 62 (2000). 
Section 5 of the Fourteenth Amendment to extend the prohibitions of the Age Discrimination in Employment Act (ADEA) to bind state governments. ${ }^{118}$ In the course of answering this question in the negative, the Court used a test that required "a congruence and proportionality between the injury to be prevented or remedied and the means adopted to that end." 119 To apply this test, the Court had to compare the kind of age discrimination that would be prohibited by the Equal Protection Clause with the kind of discrimination that was in fact prohibited by the statute. In making this comparison, the Court made it clear that, unlike the ADEA, the Equal Protection Clause does not protect individuals. Specifically, the Court stated:

Under the Fourteenth Amendment, a State may rely on age as a proxy for other qualities, abilities, or characteristics that are relevant to the State's legitimate interests. The Constitution does not preclude reliance on such generalizations. That age proves to be an inaccurate proxy in any individual case is irrelevant. ${ }^{120}$

The Kimel Court went on to explain that the constitutionality of age classifications was not to be determined "on a person by person basis." " the other hand, the statutory language of the ADEA specifically made unlawful "discriminat[ion] against any individual . . . because of such individual's age." 122 This statutory language thus created "a presumption in favor of requiring . . . [an] individualized determination." " 23 The Court thus identified the clear distinction between the Equal Protection Clause, which allows for generalizations that may not be true in individual cases, and the ADEA, which protects each individual person from discrimination. Given that difference, the Court determined that Congress did not have authority under Section 5 of the Fourteenth Amendment to adopt the ADEA because the conduct prohibited by the statute was much broader than, and thus not congruent and proportional to, the conduct prohibited by the Equal Protection Clause. ${ }^{124}$ The Court's opinion in Kimel is thus very strong evidence that the Equal Protection Clause does not protect individual rights.

118. Id. at $66-67$.

119. Id. at 81 (quoting City of Boerne v. Flores, 521 U.S. 507, 520 (1997)).

120. Id. at 84 (emphasis added).

121. Id. at $85-86$.

122. 29 U.S.C. $\S 623(\mathrm{a})(1)(2006)$.

123. Kimel, 528 U.S. at 87.

124. Id. at $84-87$. 


\section{The INDIVIDUAL RIGHTS VERSION OF EQUAL PROTECTION}

The preceding section demonstrated the pervasiveness in the Supreme Court of the view that the Equal Protection Clause serves as a limit on government classification and nothing more. This has been true from the Court's earliest nineteenth century equal protection cases to the Kimel case in 2000. Even during this time period, however, the Court has on occasion described a version of the Equal Protection Clause that appears to protect individual rights. The starting point of this individual rights view of equal protection is the language of the Equal Protection Clause itself, which makes no mention of the term "classification" and states that no state shall "deny to any person within its jurisdiction the equal protection of the laws." ${ }^{.25}$ It is not initially implausible to claim that this language creates a personal right. Further, when plaintiffs prevail in cases in which they have made equal protection arguments, the remedy often appears to be protecting an individual right. Thus, for example, when the petitioner in Skinner found out that he was not going to be sterilized, it is likely that he viewed that news as the most profound protection of a very personal right. However, this individual rights interpretation of Skinner is misleading and unnecessary. This section will examine the cases that speak of equal protection as a protector of individual rights and will demonstrate that the individual rights language in those cases is unnecessary to the ultimate decision.

\section{A. Individual Rights Reasoning in Cases Challenging Racial Classifications}

The foundational case for the individual rights version of equal protection is Shelley v. Kraemer, ${ }^{126}$ the first in a small set of cases in which the Supreme Court has described the Equal Protection Clause as protecting an individual right. In Shelley, the issue before the Court was whether judicial enforcement of a racially restrictive covenant that prohibited the sale of property to black persons violated the Equal Protection Clause. ${ }^{127}$ The homeowners who were defending the enforcement of the covenant argued that there was no discrimination involved because state courts would also be willing to enforce 
a restriction on sales to white persons. ${ }^{128}$ In rejecting this "equal discrimination" argument, the Court explained:

But there are more fundamental considerations. The rights created by the first section of the Fourteenth Amendment are, by its terms, guaranteed to the individual. The rights established are personal rights. It is, therefore, no answer to these petitioners to say that the courts may also be induced to deny white persons rights of ownership and occupancy on grounds of race or color. Equal protection of the laws is not achieved through indiscriminate imposition of inequalities. ${ }^{129}$

This language might be taken to support an individual personal right of equal protection but, in fact, the case as a whole does not support this view. The most obvious problem with this use of Shelley is that it ignores the fact that the case involved a challenge to a racial classification, not a claim of harm to an individual person. The Court in Shelley was quite explicit about the class-based nature of the issue it was considering:

The restrictions of these agreements, rather, are directed toward a designated class of persons and seek to determine who may and who may not own or make use of the properties for residential purposes. The excluded class is defined wholly in terms of race or color; "simply that and nothing more."130

Shelley is clearly a case within the mainstream view of equal protection as a limitation on classification in general and on racial classifications in particular.

As for the individual, personal rights language in Shelley, it was unnecessary to the Court's holding that invalidated a racial classification. The problem in Shelley was a racial classification adopted to discriminate against a racial minority. As the Court has made clear, giving effect to racial antagonism is never a permissible governmental interest. ${ }^{131}$ This explains what is wrong with a racially restrictive covenant without any need to discuss individual or personal rights. By way of comparison, in Loving v. Virginia ${ }^{132}$ the Court faced a similar "equal discrimination" argument but responded without discussing personal rights. In Loving, the Court reviewed a statute that

128. Id. at 21.

129. Id. at 22 .

130. Id. at 10 (quoting Buchanan v. Warley, 245 U.S. 60, 73 (1917)).

131. E.g., Korematsu v. United States, 323 U.S. 214, 216 (1944) ("Pressing public necessity can sometimes justify the existence of such restrictions [on a single racial group]; racial antagonism never can.").

132. Loving v. Virginia, 388 U.S. 1 (1967). 
prohibited interracial marriage. ${ }^{133}$ As in Shelley, the statute was defended with an "equal discrimination" argument, that the state was equally willing to enforce the prohibition of interracial marriage against both black and white persons. ${ }^{134}$ The Court rejected that argument on the grounds that the statutes contained "racial classifications" and that "the fact of equal application does not immunize the statutes from the very heavy burden of justification which the Fourteenth Amendment has traditionally required of state statutes drawn according to race." ${ }^{135}$ Thus, the problem the Court identified in Loving, and which it ought to have identified in Shelley, was an indefensible racial classification, not an invasion of a personal right.

After Shelley, the individual rights arguments in the Supreme Court usually arose in affirmative action cases, beginning with Justice Powell's opinion in Regents of the University of California v. Bakke. ${ }^{136}$ The Bakke case involved a challenge to a race-conscious admissions policy at the University of California Medical School at Davis under which sixteen of the one hundred seats in the class had been set aside for minorities. ${ }^{137}$ The judgment of the Court invalidated the program, although with no majority opinion. Although no other Justice joined with Justice Powell, his opinion was widely viewed as determinative of the result and thus accorded great weight. ${ }^{138}$ In his opinion, Powell argued that all racial classifications, including those that purported to be benign, should be subjected to strict scrutiny. ${ }^{139}$ Powell defended this claim with a citation to the "individual" and "personal rights" language in Shelley as support for the view that the rights established by the Equal Protection Clause are personal rights. ${ }^{140}$ Justice Powell's concluding words on the subject seemed to be a strong endorsement of the individual rights position.

If it is the individual who is entitled to judicial protection against classifications based upon his racial or ethnic background because such distinctions impinge upon personal rights, rather than the individual only because of his membership in a

133. Id. at 2 .

134. $I d$. at $7-8$.

135. Id. at 9 .

136. Bakke, 438 U.S. 265.

137. The groups benefitted by this program were blacks, Chicanos, Asians, and American Indians. Id. at 274 .

138. E.g., Grutter v. Bollinger, 288 F.3d 732 (6th Cir. 2002), aff'd, 539 U.S. 306 (2003) (finding that Justice Powell's opinion binding on the court under Marks v. United States, 430 U.S. 188, 193 (1977) and that it remains the law until the Supreme Court instructs otherwise); contra Hopwood v. Texas, 78 F.3d. 932, 944 (5th Cir. 1996) (“Justice Powell's view in Bakke is not binding precedent on this issue.").

139. Id. at 291.

140. Id. at 289 . 
particular group, then constitutional standards may be applied consistently. ... The Constitution guarantees that right to every person regardless of his background. ${ }^{141}$

Once again, as in Shelley, these are fine-sounding words, but they are irrelevant to the issue before Powell in Bakke. As in Shelley, the Bakke case was about a challenge to a racial classification - the racial preference in medical school admissions at the California Medical School at Davis. Powell's opinion reached the conclusion that strict scrutiny should be extended to all racial classifications, including those that disadvantage the white majority, but, as in Shelley, this conclusion can be explained without reference to an individual or personal right of equal protection. It is plausible to assert, as Powell did, that racial classifications are always suspect because racial classifications have historically been used for invidious purposes, ${ }^{142}$ the benign or invidious character of a racial classification is not always obvious, ${ }^{143}$ and race-conscious decision-making tends to promote race consciousness. ${ }^{144}$ Powell was identifying what he thought was the proper standard of review of a racial classification. His personal rights rhetoric was irrelevant.

In 1990, in Metro Broadcasting, Inc. v. F.C.C., ${ }^{145}$ the Court upheld certain minority preference policies of the FCC. The Court used intermediate, rather than strict, scrutiny, on the ground that the minority preference had been adopted by Congress, a co-equal branch of government with broad powers granted by the Constitution. ${ }^{146}$ Thus, according to the majority, it was appropriate to apply one (more lenient) standard of review to racial classifications by the federal government, but a different (more demanding) standard to racial classifications by state governments. ${ }^{147}$ The majority opinion made no mention of individual or personal rights but rather held that the benign racial classification adopted by the FCC was substantially related to the important governmental objective of broadcast diversity. ${ }^{148}$

Justice O'Connor wrote a dissenting opinion that rebuked the majority for its failure to give effect to the personal nature of the equal protection guarantee. She insisted that "[a]t the heart of the Constitution's guarantee of equal protection lies the simple command that the Government must treat

141. Id. at 299.

142. E.g., Strauder, 100 U.S. 303; Plessy, 163 U.S. 537; Brown, 347 U.S. 483.

143. Bakke, 438 U.S. at 298.

144. Id. at 298-99.

145. Metro Broadcasting, Inc. v. F.C.C., 497 U.S. 547 (1990).

146. Id. at 563 .

147. Id. at 563-67.

148. Id. at 566 . 
citizens 'as individuals, not as simply components of a racial, religious, sexual or national class." "149 For O'Connor, this meant "the Government may not allocate benefits and burdens among individuals based on the assumption that race or ethnicity determines how they act or think." 150 The racial preference that the majority approved was for O'Connor, inconsistent with "the Nation's widely shared commitment to evaluating individuals upon their individual merit." ${ }^{151}$ One need not contest Justice O'Connor's commitment to evaluating individuals on their individual merit, but it is hard to see how that commitment receives constitutional protection from the Equal Protection Clause. That clause is ordinarily viewed as serving merely as a limit on government classification, and the validity of a governmental race classification was precisely the issue before Court in Metro Broadcasting. The Supreme Court would later, in Adarand Constructors, Inc. v. Pena, ${ }^{152}$ overrule Metro Broadcasting and decide that all racial classifications, whether made by state or federal government, were to be subject to strict scrutiny. ${ }^{153}$ This higher level of scrutiny would make it harder for the FCC preference to survive constitutional scrutiny, but that would not necessarily mean that the Equal Protection Clause was protecting an individual right.

The Adarand case involved a challenge to a program of the federal government that created financial incentives to encourage contractors on federal projects to give a preference to minority subcontractors. ${ }^{154}$ The Court justified its holding that all racial classifications should be subject to strict scrutiny by reference to three general propositions that it said had been established in its previous cases: skepticism, consistency, and congruence. ${ }^{155}$ According to the Court, these three propositions all derive from the basic principle that the Fifth and Fourteenth Amendments to the Constitution protect persons not groups. It follows from that principle that all governmental action based on race-a group classification long recognized as "in most circumstances irrelevant and therefore prohibited,"-should be subjected to detailed judicial inquiry to ensure that the personal right to equal protection of the laws has not been infringed. ${ }^{156}$

149. Id. at 602 (O’Connor, J., dissenting) (citing Ariz Governing Comm. for Tax Deferred Annuity and Deferred Comp. Plans v. Norris, 463 U.S. 1073, 1083 (1983)).

150. Id.

151. Id. at 604 .

152. Adarand Constructors, Inc. v. Pena, 515 U.S. 200 (1995).

153. Id. at 227.

154. Id. at 205-06.

155. Id. at $223-24$.

156. Id. at 227 (quoting Hirabayashi v. United States, 320 U.S. 81, 100 (1943) (emphasis in 
The Court explained further that "whenever the government treats any person unequally because of his or her race, that person has suffered an injury that falls squarely within the language and spirit of the Constitution's guarantee of equal protection." "157 The majority criticized Justice Stevens' dissenting opinion, which had argued that it was appropriate to review benign racial classifications more generously than invidious racial classifications, as inconsistent "with the long line of cases understanding equal protection as a personal right." 158

The Court's Adarand opinion thus is an apparent endorsement of an individual rights view of equal protection but it is also subject to the same criticism that was directed at Powell's Bakke opinion. For all of its pleasing rhetoric, the individual rights reasoning is irrelevant to the Court's decision. Once again, the complaint in Adarand was directed at a racial classification, and the Court's conclusion that strict scrutiny is the proper standard of review for all racial classifications is a plausible, if not necessary, conclusion to be drawn from the Court's precedents and from the fact that racial classifications in American history have almost always been invidious. ${ }^{159}$ The language of individual and personal rights, however, adds nothing to the analysis and is not capable of transforming a traditional equal protection challenge to a classification into a version of the Equal Protection Clause that guarantees individual rights.

In Grutter v. Bollinger, ${ }^{160}$ the Court upheld a race-conscious admissions policy at the University of Michigan Law School and, in doing so, used the language of equal protection as an individual right. The University of Michigan Law School had adopted an admissions policy under which, with the goal of producing a diverse student body, the admissions committee used race as one of the factors in admissions decisions in order to admit a "critical mass" of minority students. ${ }^{161}$ The Court upheld this limited use of race in the context of University admissions, finding that the race-conscious decisions were narrowly tailored to achieve a compelling interest in diversity. ${ }^{162}$ In determining whether or not the law school's program was "narrowly tailored" to achieve its diversity goal, the Court insisted that, although race could be

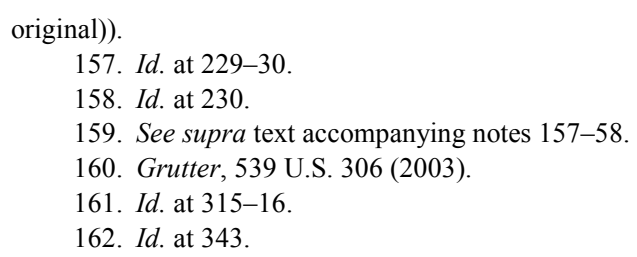


one of the factors the committee might consider, each applicant must receive "individualized consideration," 163 the university could not insulate minority applications from competition with other applicants, ${ }^{164}$ and the process

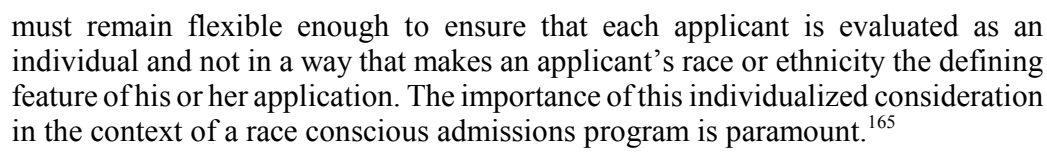

The Court upheld the Michigan program because "the Law School engages in a highly individualized, holistic review of each applicant's file, giving serious consideration to all the ways an applicant might contribute to a diverse educational environment. The Law School affords this individualized consideration to applicants of all races."166

It must be admitted that the majority opinion in Grutter does initially sound like a ringing endorsement of an individual rights view of equal protection. However, this initial impression does not hold up to close scrutiny, for as Justice O'Connor wrote, "[c]ontext matters when reviewing race based governmental action under the Equal Protection Clause." ${ }^{167}$ The context that mattered in Grutter was that, although it has the appearance of a personal rights case, it too is a case that challenges a racial classification. The personal rights language was not part of a general challenge to the racial classification but was limited to the application of the "narrowly tailored" portion of the strict scrutiny standard of racial classifications. The Court's insistence on individualized consideration of each application was part of its judgment that the consideration of race in the admissions process was "narrowly tailored," that is, that there was no other, non-racial way to achieve the law school's diversity goal. The Court's insistence on individual consideration here is not surprising since the "narrowly tailored" portion of the strict scrutiny test is sufficiently demanding that a classification that harms individuals will not likely satisfy the test. That does not, however, transform a limitation on classification into a protector of individual rights.

Subsequently, in Parents Involved in Community Schools v. Seattle School Dist. No. $1,{ }^{168}$ the Court invalidated race-conscious student assignment

163. Id. at 334 .

164. Id. (quoting Bakke, 438 U.S. at 317).

165. Grutter, 539 U.S. at 337.

166. Id. at 337.

167. Id. at 327 .

168. Parents Involved in Cmty. Sch. v. Seattle Sch. Dist. No. 1, 127 S. Ct. 2738 (2007). 
policies in two public school districts. The Court was of the view that the policies had been adopted not to promote diversity but to achieve a certain level of racial balance in individual schools, "an objective [the] Court has repeatedly rejected as illegitimate." 169 In the course of its opinion, the Court once again resorted to personal rights language to explain its result:

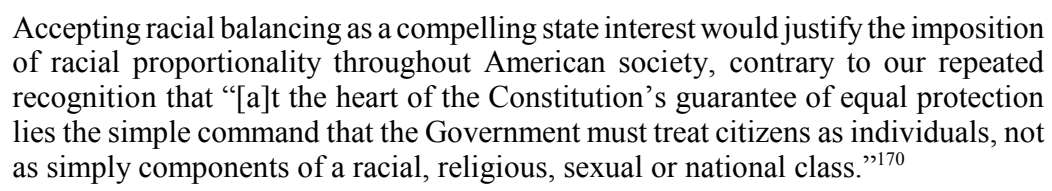
of racial proportionality throughout American society, contrary to our repeated recognition that "[a]t the heart of the Constitution's guarantee of equal protection lies the simple command that the Government must treat citizens as individuals, not as simply components of a racial, religious, sexual or national class."

One need not disagree with the result in Seattle School District to recognize that the individual rights rhetoric is unnecessary to that result. To the extent that the Court had correctly identified the purpose of the school board as the achievement of racial balance, Supreme Court precedent had already made clear that, just as racial antagonism is never a permissible governmental purpose, ${ }^{171}$ so also racial preference for its own sake is always an impermissible purpose. ${ }^{172}$

The cases in this section all share a common structure. They all insist that equal protection rights are personal and individual and yet they make this claim in cases where the constitutional claim is a very traditional challenge to a racial classification. The "personal" and "individual" language appears either when the Court is addressing an "equal discrimination" defense to a racial classification, determining the proper standard of review for a racial classification, or determining whether a racial classification satisfies the "narrowly tailored" portion of strict scrutiny. In no sense do any of these cases provide any support for a freestanding individual right of equal protection apart from a classification.

\section{B. Individual Rights Reasoning in Cases Challenging Gender Classifications}

The Court has also used individual rights language in equal protection cases that challenged gender classifications. Thus, for example, in Frontiero

169. Id. at 2755 .

170. Id. at 2757 (quoting Miller v. Johnson, 515 U.S. 990, 991 (1995)).

171. Korematsu, 323 U.S. at 216.

172. Bakke, 438 U.S. at 307. 
v. Richardson, ${ }^{173}$ the Court reviewed a federal statute under which the wives of military personnel were presumed to be dependent in order to qualify for military benefits, but husbands of military personnel were not considered dependent unless they had actually proved their financial dependence. ${ }^{174}$ The Court invalidated the statute and, in a plurality opinion, explained what was wrong with that gender-based presumption. For the plurality, sex, "like race and national origin, is an immutable characteristic determined solely by accident of birth" 175 and thus to impose disabilities on the basis of sex would seem to violate "the basic concept of our system that legal burdens should bear some relationship to individual responsibility." 176 Further, because "the sex characteristic frequently bears no relation to ability to perform or contribute to society," 177 classifications based on sex "often have the effect of invidiously relegating the entire class of females to inferior legal status without regard to the actual capabilities of its individual members." ${ }^{178}$ These statements seem to suggest that what is objectionable about gender classifications is that they fail to take into account individual differences within the sexes; that is, they involve broad generalizations that are not universally true, and thus, wrongfully ignore individual merit. Thus, equal protection would appear to protect individual rights in the context of gender.

That appearance, however, is misleading and wrong. As with the earlier cases on race, the individual rights claims in Frontiero were made in a case challenging a classification, and the individual rights reasoning was merely part of the Court's analysis of the appropriate standard of review. Further, the problem with giving weight to the Court's focus on "individual responsibility" and "individual differences" is that the Court itself has ignored that focus in subsequent cases. In Nguyen $v$. INS,${ }^{179}$ for example, the petitioner challenged a federal statute that set forth the requirements for the acquisition of United States citizenship by persons born outside of the United States to a citizen parent and a noncitizen parent who were not married to each other. The statute required a citizen/father to go through one of three formal paternity proceedings before the child reached the age of eighteen but imposed no similar requirement on a citizen/mother. ${ }^{180}$ The Court upheld this gender

173. Frontiero v. Richardson, 411 U.S. 677 (1973) (plurality opinion).

174. Id. at $678-79$.

175. Id. at 686 .

176. Id. (quoting Weber v. Aetna Cas. \& Ins. Co., 406 U.S. 164, 175 (1972)).

177. Frontiero, 411 U.S. at 686.

178. Id. at 687.

179. Nguyen v. INS, 533 U.S. 53 (2001).

180. Id. at 59-60 (citing 8 U.S.C. $\S \S 1401$ (g)-1409(a) (1994)). 
distinction because it found that mothers and fathers are not similarly situated in this situation.

In the case of the father, the uncontestable fact is that he need not be present at the birth. If he is present, furthermore, that circumstance is not incontrovertible proof of fatherhood.... "The mother carries and bears the child, and in this sense her parental relationship is clear. The validity of the father's parental claims must be gauged by other measures."181

The Court then determined that the gender classification that treated mothers and fathers differently was substantially related to the important governmental interests of assuring that a biological parent-child relationship exists and ensuring that the parent and child have an actual practical relationship. ${ }^{182}$ Thus, the Court upheld the statute, and the petitioner was subject to deportation. Strangely, though, for a Court that earlier had insisted that "legal burdens should bear some relationship to individual responsibility," 183 the Nguyen Court did not appear to be at all troubled that the petitioner was in fact the son of his citizen/father. ${ }^{184}$ The generalizations about fathers and mothers and proof of parenthood because of presence at birth were not relevant to Nguyen since the Court conceded parenthood. Nevertheless, explained the Court, "none of our gender based classification equal protection cases have required that the statute under consideration must be capable of achieving its ultimate objective in every instance." 185 Once again, since the classification satisfied the required standard, the individual who was adversely affected did not matter.

The Court has also upheld gender classifications in the affirmative action context, with little concern for the effect of generalizations on individuals. In Kahn v. Shevin, ${ }^{186}$ the Court upheld a property tax exemption for widows but not widowers on the ground that it was "reasonably designed to further the state policy of cushioning the financial impact of spousal loss upon the sex for which that loss imposes a disproportionately heavy burden." ${ }^{187}$ Justice Brennan, in dissent, pointed out that the exemption, although designed to address past economic discrimination against women, would extend its benefit

181. Nguyen, 533 U.S. at 62 (quoting Lehr v. Robertson, 463 U.S. 248, 260, n.16 (1983)).

182. Id. at $62-70$.

183. Weber v. Aetna Casualty \& Surety Co., 406 U.S. 164, 175 (1972); Frontiero, 411 U.S. at 686.

184. Id. at 57.

185. Id. at 70 .

186. Kahn v. Shevin, 416 U.S. 351 (1974).

187. Id. at 355 . 
not only to needy women but to the "financially independent heiress" 188 as well, and of course no needy widowers would be benefited. Justice White also critiqued the woman-only exemption:

I perceive no purpose served by the exemption other than to alleviate current economic necessity, but the State extends the exemption to widows who do not need the help and denies it to widowers who do. It may be administratively inconvenient to make individual determinations of entitlement and to extend the exemption to needy men as well as needy women, but administrative efficiency is not an adequate justification for discriminations based purely on sex. ${ }^{189}$

White's dissent makes this point: the majority's decision had the effect of upholding a gender classification that was entirely unconcerned with the individual circumstances of any particular widow or widower. Since the classification, however, satisfied the intermediate scrutiny standard, concerns for individuals were not relevant.

Perhaps the strongest rejection of the individual rights version of equal protection in the gender context is the widespread acceptance, both by courts and by society, of gender-segregated sports programs, at every level, from youth, through high school, college, and professional. The very powerful language of Brown v. Board of Education ${ }^{190}$ that separate educational facilities are inherently unequal is not applied to gender segregation in sports. Although it is not immediately clear why gender segregation in sports is not treated more skeptically as a constitutional matter, it is clear as a practical matter that there are very good reasons for separating men and women in sports. Donna Lopiano, formerly the chief executive officer of the Women's Sports Foundation, summarized how the inherent biological differences between the sexes justified gender-segregated sports programs. She explained:

Sport is basically a strength, speed and reaction time activity involving propelling a mass through space or overcoming the resistance of a mass. Physiologically and anatomically you cannot compare highly skilled male and female athletes on these parameters because of the inherent biological differences between the sexes. Men are stronger, faster, have better reaction time and more muscle tissue per unit of body mass. That is why athletic teams and competition are sex separate. Women compete against women and men compete against men. Women excel in balance, accuracy and fine motor skill activities while men excel in strength, speed and gross motor skills. ${ }^{191}$

188. Id. at 360 (Brennan, J., dissenting).

189. Id. at 361 (White, J., dissenting).

190. 347 U.S. at 495.

191. Ass'n for Intercollegiate Athletics for Women v. Nat'l Collegiate Athletic Ass'n, 558 F. Supp. 
Further, a recent New York Times article emphasized the importance of the hormone testosterone to athletic performance. Testosterone "affects everything from muscle size and strength to the size of the heart to the amount of oxygen-carrying blood cells in the body to the percentage of fat on an athlete's body. Every one of those effects gives men a performance advantage." 192 Thus, the decision to have males and females compete separately in sports seems to be both prudent in terms of avoiding injury and fair in terms of providing equal athletic opportunity to women.

All of these points conceded, the separation of men and women in sports is inconsistent with an individual, personal rights view of equal protection. Such segregation is based on generalizations about the typical physical makeup of men and women but makes no allowance for individuals who do not fit the mold. What about the woman, even if it is a rare case, who can compete successfully against men in sports? Why should a generalization about women as a class prevent her from being judged in a tryout on the basis of her individual ability? It was just this kind of generalization about the typical physical capacities of women that the Court found to be constitutionally unacceptable in United States v. Virginia.${ }^{193}$ In that case, the Court reviewed the all-male student policy at the Virginia Military Institute and found that it violated the Equal Protection Clause. ${ }^{194}$ In explaining what was the matter with the exclusion of women from VMI, the Court insisted that "generalizations about 'the way women are,' estimates of what is appropriate for most women, no longer justify denying opportunity to women whose talent and capacity place them outside the average description." ${ }^{195}$ In this regard, the Court noted that "some women are capable of all of the individual activities required of VMI cadets . . . and can meet the physical standards [VMI] now impose[s] on men." 196 It was for these women that the VMI Court crafted a remedy.

Notably, this very critique of the VMI program appears to be equally applicable to the very widely adopted gender segregation of sports programs. Such separation of males and females makes sense as a general matter, but it

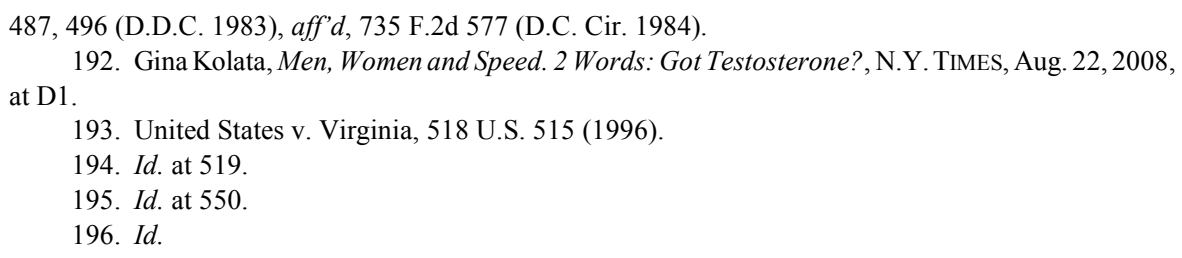


ignores the situations of individual women to whom the generalization does not apply-those women who could compete successfully with men in athletics. For the courts, however, these individual cases do not matter. Thus, for example, in O'Connor v. Board of Education of School District 23, ${ }^{197}$ a federal district court considered the claim of an outstanding young female basketball player who wanted to play in the boys' league but was forced to play with the girls. The court succinctly identified the dilemma: "Karen O'Connor is an extraordinarily gifted basketball player. She is also female. Therein lies the problem." 198

On the one hand, the defendant school board in the case did not dispute Karen's claim that "only participation on the boys' team will provide her with a level of competition suited to her level of skills." ${ }^{199}$ On the other hand, the plaintiffs conceded that the separation of boys and girls in the basketball program was substantially related to the important goal of maximizing the participation of both sexes in interscholastic sports "[s]ince boys, on the whole, are substantially better basketball players than are girls." ${ }^{200}$ The issue, then, was "whether the defendants' policies need to be justified only in terms of differences between the sexes as a whole or whether they must also be justified as applied to Karen's particular case." ${ }^{201}$ The district court then noted Supreme Court precedents that suggested that, given "the treacherous nature of generalizations about the sexes, it might be inappropriate to apply the generalization without regard for the individual case. ${ }^{" 202}$ Ultimately, however, the district court decided to make use of such a treacherous generalization, since it adopted the view set forth in Justice Stevens' earlier opinion denying a stay in the case: "If the classification is reasonable in substantially all of its applications, I do not believe that the general rule can be said to be unconstitutional simply because it appears arbitrary in an individual case." ${ }^{203}$ The district court then granted the school district's motion for summary judgment, and Karen O'Connor was left to play basketball in the girls' league. This result is inconsistent with an understanding of equal protection as a protector of individual rights.

197. O’Connor v. Bd. of Educ. of Sch. Dist. 23, 545 F. Supp. 376 (N.D. Ill. 1982).

198. Id. at 377.

199. Id. at 379 .

200. Id.

201. Id.

202. Id. at 379-80.

203. Id. at 381 (quoting from O'Connor v. Bd. of Educ. of Sch. Dist. 23, 449 U.S. 1301, 1306 (1980) (Stevens, J., as Circuit Judge)). 


\section{CONCLUSION}

Under longstanding Supreme Court precedent, the Equal Protection Clause serves as a limitation on governmental classification and not as a protector of individual rights. Occasional Supreme Court comments to the contrary are misleading and, in almost all cases, incorrect. When racial or gender classifications are found to be unconstitutional, that result flows from the demanding nature of strict or intermediate scrutiny. A successful plaintiff in such a suit will often receive the individual relief he or she sought. Thus, for example, Alan Bakke was admitted to medical school and female plaintiffs were admitted to VMI. In these situations, it may seem to the prevailing party that his or her individual relief is evidence of the individual and personal nature of the protections of the Equal Protection Clause. That perception, however, is incorrect. Such individual relief is a mere byproduct of the invalidation of a classification because the classification does not meet the particular level of scrutiny demanded. The appeal to individual or personal rights under the Equal Protection Clause diverts attention from what ought to be the concern of courts - whether or not a classification is sufficiently correlated with a sufficient purpose. That is what the Equal Protection Clause demands, and that is what courts should require. 
